\title{
Looking north of the border
}

\section{COMMENTARY ON... LASTING POWERS OF ATTORNEY: IMPLICATIONS FOR CLINICIANS}

\section{Donald Lyons}

\begin{abstract}
SUMMARY
Scottish legislation on incapacity differs significantly from English and Welsh legislation. Clinicians must be aware of the authority of attorneys, especially in relation to welfare and medical treatment. The number of welfare attorneys is growing and they may not be aware of how best to use their powers.
\end{abstract}

\section{DECLARATION OF INTEREST}

None.

It may be of interest to compare the article by Curtice and colleagues (2012, this issue) with the situation in Scotland. Powers of attorney for financial and welfare matters are the subject of Part 2 of the Adults with Incapacity (Scotland) Act 2000 (the 2000 Act). This Act replaced a patchwork of archaic and confusing legislation and provided a framework for decisions where adults lack or lose capacity (Ward 2003).

\section{Incapacity in Scotland}

The definition of incapacity in Scotland is somewhat different from that in England and Wales. Section 1(6) of the 2000 Act defines incapacity as meaning incapable of acting, making decisions, understanding decisions, communicating decisions or retaining the memory of decisions by reason of mental disorder or inability to communicate because of physical disorder. 'Incapable of acting' is a crucial difference and does not appear in the Mental Capacity Act 2005 (the 2005 Act). There are situations where an adult must be able to act on a decision to secure his/her own welfare or finances. For example, granting or revoking a power of attorney requires positive action from the adult. Clinicians should be wary when relatives or friends appear to be coercing the adult into action. This is one issue in an ongoing investigation by the Mental Welfare Commission for Scotland.

\section{Principles in Scottish law}

As with the 2005 Act, Scottish legislation opens with a set of principles: benefit to the adult; least restriction of freedom; taking account of the adult's views; consulting relevant others; and (in some situations) helping the adult to retain existing skills and develop new skills. The principle of presumption in favour of capacity is a principle in Scots law and did not need to be restated in the 2000 Act. As with the 2005 Act, clinicians in Scotland are required to presume capacity unless there is evidence to the contrary. The rest of this commentary will focus on powers of attorney in Scotland and how they differ from England and Wales.

\section{'Old' powers of attorney}

'Old' powers of attorney, granted before the 2000 Act was implemented, are still in existence and valid. A power of attorney granted from 1991 onwards is taken to persist when the adult loses capacity. Generally, it will have the same force as a continuing (financial) power of attorney under the 2000 Act and it does not require to be registered with the Public Guardian. Few, if any, 'old' powers of attorney addressed welfare matters.

\section{‘New' powers of attorney}

'New' powers of attorney can have financial and/or welfare powers. A medical practitioner, solicitor or member of the Faculty of Advocates in Scotland must certify capacity. Solicitors should ask for a medical opinion on capacity to grant powers if the person appears to have a significant mental disorder. There is no clear mechanism to challenge capacity to grant powers at a later date. The document must be registered by the Office of the Public Guardian in Scotland before it can be activated. Continuing attorney powers for financial matters can be used at any time. Welfare powers only become active when the adult no longer has capacity to make the specific decision in question.

The Office of the Public Guardian can investigate the use of financial powers, but only when the adult does not have capacity. It is assumed that a capable adult will take action if there is a suspicion of misuse of powers by the attorney. In advising the Office of the Public Guardian about
Donald Lyons is an old age psychiatrist and has been head of the Mental Welfare Commission for Scotland since 2003.

Correspondence Dr Donald Lyons, Chief Executive, Mental Welfare Commission for Scotland, 91 Haymarket Terrace, Edinburgh EH12 5HE, UK. Email: Donald. lyons@mwcscot.org.uk

${ }^{\dagger}$ See pp. 205-212, this issue. 
capacity, clinicians must consider whether the adult has the capacity to act to challenge the use of the attorney's powers. Local authorities have a duty to investigate the use of welfare powers. The Mental Welfare Commission for Scotland also has investigatory powers that may be relevant.

There are now likely to be at least 200000 active powers of attorney in Scotland. In 2009-2010, the Office of the Public Guardian registered more than 38000 new powers of attorney (Table 1). More than $90 \%$ of those contained welfare powers (www.publicguardian-scotland.gov.uk/whatwedo/ statistics.asp). The number of new registrations is continuing to rise year on year. Therefore, it is increasingly important that clinicians understand their responsibilities, especially in relation to welfare and treatment issues, when there is a welfare attorney.

\section{Are the powers in place?}

Many people purport to have power of attorney and insist that they can make decisions about welfare and treatment matters. Clinicians should ask for a copy of the powers. The power must be explicit in the document. For example, the attorney cannot consent or refuse to consent to medical treatment unless the power to do so is explicitly stated. It is best practice to retain a copy of the powers in the clinical record.

\section{Are the powers exercisable?}

The attorney can only make welfare decisions if the adult lacks capacity. Also, at best, the attorney can only make decisions that the adult could make him/herself if capable. For example, the attorney cannot insist on the provision of a service for which the adult does not qualify. Whereas the attorney can agree to admission to a care home and should

\section{TABLE 1}

Powers of attorney registered in Scotland 2001-2010

\begin{tabular}{|lcccc|}
\hline Year & Financial only & Welfare only & $\begin{array}{c}\text { Both financial } \\
\text { and welfare }\end{array}$ & Total \\
\hline $2001 / 02$ & 3947 & 197 & 1448 & 5592 \\
\hline $2002 / 03$ & 6382 & 468 & 3508 & 10358 \\
\hline $2003 / 04$ & 7554 & 1096 & 5794 & 14444 \\
\hline $2004 / 05$ & 8044 & 1356 & 8713 & 18113 \\
\hline $2005 / 06$ & 8062 & 1908 & 12927 & 22897 \\
\hline $2006 / 07$ & 6626 & 2097 & 17745 & 26468 \\
\hline $2007 / 08$ & 5617 & 2290 & 24159 & 32066 \\
\hline $2008 / 09$ & 3059 & 1351 & 26327 & 30737 \\
\hline $2009 / 10$ & 2706 & 1318 & 34683 & 38707 \\
\hline Total & & & & $\mathbf{1 9 9 3 8 2}$ \\
\hline
\end{tabular}

Source: www.publicguardian-scotland.gov.uk/whatwedo/statistics.asp. have a say in the choice of home, the attorney cannot insist that the local authority pays for care in a particular home if the adult is not assessed as needing that level of care. Of course, it is different if the attorney is using the adult's funds to pay for care (but see below on raising concerns).

\section{Consent to medical treatment}

A welfare attorney with the specific authority can consent or refuse to consent to treatment for the adult. There is no power to insist that any particular treatment is given. The prescribing practitioner has the duty to consult the welfare attorney unless it is impracticable to do so. Best practice is to agree a plan with the attorney, with agreement on when specifically the attorney would wish to be consulted. If the attorney refuses to consent, treatment cannot be given (except to save life) unless authorised by an independent 'nominated medical practitioner' appointed by the Mental Welfare Commission for Scotland. His/her decision stands unless challenged by application to the Court of Session.

Attorneys have no power to consent where the adult is treated for mental disorder under Part 16 of the Mental Health (Care and Treatment) (Scotland) Act 2003. Also, some treatments given under the 2000 Act are governed by regulations (Section 48), including sterilisation, abortion, medication to reduce sex drive and electroconvulsive therapy. Welfare attorneys do not have the authority to consent or refuse to consent to these treatments. The principles of the Act do, however, require clinicians to take their views into account.

End-of-life decisions are particularly complicated and are well covered by available guidance (General Medical Council 2010). Unlike the 2005 Act, advance statements do not have formal status. If an adult makes an advance statement refusing life-sustaining treatment, the clinician and the attorney must have regard to that statement. Giving treatment that is in conflict with a competently made advance statement could be a common-law assault. Clinicians should seek advice from solicitors or their professional indemnity organisation.

\section{What if the adult resists a decision made by the welfare attorney?}

My advice is that the attorney can use reasonable persuasion but not force. A welfare guardian, appointed by a sheriff, can apply to the Sheriff Court for a compliance order under Section 70 of the 2000 Act. This option is not open to a welfare attorney. 


\section{What to do if concerned about the use of powers}

The attorney, or anyone else with an interest, can ask the sheriff for a direction as to the use of powers (Section 3 of the 2000 Act). The sheriff can then issue a judgment declaring whether a particular power can or cannot be used in a particular situation. If there are more general concerns about the actions of an attorney, any person with an interest can apply to the sheriff under Section 20 of the Act. The sheriff could revoke the power or make an order that the attorney is supervised by the Office of the Public Guardian (for continuing attorneys) or local authorities (for welfare attorneys).

The Mental Welfare Commission for Scotland has been concerned that welfare attorneys are unsure about how to exercise their powers and that they sometimes do not receive the support that they need to do so (Mental Welfare Commission for Scotland 2010). We have also heard from some attorneys that they have not been consulted when they should have been. Clinicians should work with attorneys, communicate well with them and make sure that everyone (including the attorneys themselves) understands the extent of the powers and how they are best used in individual clinical situations.

\section{References}

Curtice M, Katuwawela I, McCollum R (2012) Lasting powers of attorney: implications for clinicians. Advances in Psychiatric Treatment 18: 205-12.

General Medical Council (2010) Treatment and Care Towards the End of Life. Good Practice in Decision Making. GMC (http://www.gmc-uk.org/ guidance/ethical_guidance/end_of_life_care.asp).

Mental Welfare Commission for Scotland (2010) Best of Intentions: Report from Our Investigation into the Care and Treatment of Mrs I. MWCS (http://reports.mwcscot.org.uk/web/FILES/Investigationsreports/ Best_Intentions.pdf).

Ward A (2003) Adult Incapacity. Green Publishing

\title{
'Even for a violent ward...': extract from $A$ Mind That Found Itself, by Clifford Whittingham Beers
}

\author{
Selected by Femi Oyebode
}

Even for a violent ward my entrance was spectacular - if not dramatic. The three attendants regularly in charge naturally came to the conclusion that, in me, a troublesome patient had been foisted upon them. They noted my arrival with an unpleasant curiosity, which in turn aroused my curiosity, for it took but a glance to convince me that my burly keepers were typical attendants of the brute-force type. Acting on the order of the doctor in charge, one of them stripped me of my outer garments; and, clad in nothing but underclothes, I was thrust into a cell.

Few, if any, prisons in this country contain worse holes than this cell proved to be. It was one of five, situated in a short corridor adjoining the main ward. It was about six feet wide by ten feet long and of a good height. A heavily screened and barred window admitted light and a negligible quantity of air, for the ventilation scarcely deserved the name. The walls and floor were bare, and there was no furniture. A patient confined here must lie on the floor with no substitute for a bed but one or two felt druggets. Sleeping under such conditions becomes tolerable after a time, but not until one has become accustomed to lying on a surface nearly as hard as a stone. Here (as well, indeed, as in other parts of the ward) for a period of three weeks I was again forced to breathe and rebreathe air so vitiated that even when I occupied a larger room in the same ward, doctors and attendants seldom entered without remarking its quality.
Clifford Whittingham Beers (1876-1943) published A Mind That Found Itself in 1908. It is an autobiographical account of his psychiatric hospital admission and the abuses that he suffered during his treatment in hospital. In 1909 he founded the National Committee for Mental Hygiene (a reforming organisation), now renamed Mental Health America, and in 1913 he started the Clifford Beers Clinic, the first out-patient clinic for the mentally ill in the USA. This extract is from A Mind That Found Itself: An Autobiography, University of Pittsburgh Press, 1908: pp. 124-125

doi: 10.1192/apt.18.3.215 